\title{
Comparison Study of Produced Water Treatment Using Electrocoagulation and Adsorption
}

\author{
ZAMEN KARM ${ }^{1 *}$, AKEEL DHAHIR SUBHI ${ }^{2}$, RAMZY SYHOOD HAMIED ${ }^{3}$ \\ ${ }^{1,2}$ University of Technology, Department of Production Engineering and Metallurgy, Baghdad, Iraq \\ 3 University of Technology, Department of Petroleum Technology, Baghdad, Iraq
}

Abstract: In the present work, electrocoagulation and adsorption were applied as environmentally friendly methods to treat produced water $(P W)$ obtained from East Baghdad oil field. Electrocoagulation was applied using iron-iron and aluminum-aluminum electrodes while modified silica was used as adsorbent material to remove total dissolved solids $(T D S)$ and reduce electrical conductivity $\left(E_{C}\right)$ of produced water. XRD, SEM and AFM were used to characterize the modified silica. The experiments were achieved using different adsorbent doses $(0.2$ and $0.4 \mathrm{mg} / \mathrm{L})$ and contact times (30-180 min) at room temperature. The results showed that the electrocoagulation failed to treat the produced water. The surface roughness of modified silica had a significant role in adsorbing TDS. The lowest values of $T D S$ and $E_{C}$ were $513 \mathrm{mg} / \mathrm{L}$ and $781 \mu \mathrm{S} / \mathrm{cm}$, respectively, obtained using adsorbent dose of $0.4 \mathrm{mg} / \mathrm{L}$ modified silica at a contact time of $180 \mathrm{~min}$. These results were within the permissible limit according to the specifications of the WHO to provide the possibility of reuse of produced water when re-injected into oil wells.

Keywords: produced water, electrocoagulation, modified silica, adsorption, TDS, $E_{C}$

\section{Introduction}

Produced waters are the biggest origin of contamination identified with oil production, as they contain contaminants, such as hydrocarbons, inorganic compounds and metals [1,2]. Total dissolved solids (TDS) describe the inorganic salt and little amount of organic matters existed within produced water. The main components represent typically calcium, magnesium, sodium, potassium cations, carbonate, hydrogen carbonate, chloride, sulphate and nitrate anions [3]. The electrical conductivity $\left(E_{C}\right)$, on the other hand, is a measure to the capacity of water to conduct electrical current; it is directly related to the concentration of salts dissolved in produced water [4]. In produced water, the salt content varies greatly, from almost freshwater levels to salt levels that are ten times higher than sea water [5].

The TDS in produced water depends on the diverse geological territories due to distinctions in the solubility of minerals [6]. Most studies focus on treating the produced water by removing dissolved solids and thus reduce environmental damage, including sodium adsorption, which causes soil clay damage [7]. Therefore, the World Health Organization (WHO) [8] focused on regulating the acceptable level of dissolved solids in water that can be discharged into the surrounding environment to be safe [9]. Higher TDS in produced water may be due to the natural weathering of certain sedimentary rocks or some anthropogenic source, e.g., irrigation discharge, domestic effluents, and sewage effluent. For purifying produced water, many treatment technologies like chemical precipitation, adsorption, ion exchange, membrane filtration, electrochemistry, and phytoremediation are employed [10]. Electrocoagulation (EC) is a treatment technology that has several advantages including safety, does not need auxiliary chemicals, low cost, and flexibility. However, it is a complex process because it includes several chemical and physical mechanisms achieved using sacrificial electrodes, like aluminum, iron and others to supply ions in water. The coagulant is produced in situ through electrically dissolving the consumable electrodes ( $\mathrm{Fe} / \mathrm{Al}$ ) during an electrical current supply. Metal ions are generated at the anode, while hydrogen gas is liberated at the cathode [11,12].

\footnotetext{
*email:engm614@yahoo.com
} 
Adsorption technique is considered as a significant technique of solid phase extracting (SPE) for separating and removal of contaminants such as TDS. It has several advantages such as it is fast, consumes less effort, the ability to reuse adsorbent and eco-friendly [13]. Adsorption can be accomplished by using a variety of materials, including organoclays, zeolites, chitosan, activated carbon, silica and alumina [14]. Silica particles are vital metal oxides which have the ability to eliminate weighty metal ions from aqueous solutions due to their great surface area, extraordinary sorption capacity, and mechanical strength [15]. Silica adsorbent was used in previous years and became the focus of many researchers [16-19]. Recently, modified silica has been successfully applied to treat wastewater [20]. The major environmental damage resulting from pumping the produced water to the vast lands or rivers or damages related to re-injecting the produced water into the oil wells attracted researchers to reduce the dissolved solids that are the main cause of these problems. Therefore, the main purpose of this study is to investigate the enhancement of TDS removal and reduction of EC of produced water obtained from East Baghdad oil field using electrocoagulation and adsorption methods. Adsorption was performed at different adsorption parameters such as adsorbent dose and contact time using modified silica. The comparison between electrocoagulation and adsorption in the treatment of produced water is also covered.

\section{Materials and method}

\subsection{Produced Water Characteristics}

Produced water was obtained from East Baghdad oil field and its characteristics compared with drinking water [8,9] and sea water [21] are shown in Table 1. The value of $p \mathrm{H}$ was determined using a $\mathrm{pH}$ meter model Hanna Bench $p \mathrm{H} 211$ Meter/UK. Total dissolved solids (TDS) of produced water was measured according to ASTM D 5907-96a [22] using TDS device model TDS-3/India with a range of 0-999 ppm. Sulfate ions concentration was estimated in the produced water according to ASTM D 51668 [23]. Electrical conductivity $\left(\mathrm{E}_{\mathrm{C}}\right)$ of produced water was determined according to the standard D1125$95[24]$.

Table 1. Comparison of the chemical and physical characteristics of produced water with drinking water and sea water

\begin{tabular}{|c|c|c|c|c|}
\hline \multirow{2}{*}{ Characteristics } & \multirow{2}{*}{$\begin{array}{c}\text { East Baghdad Oil } \\
\text { Field }\end{array}$} & \multicolumn{2}{|c|}{ Drinking water } & \multirow{2}{*}{ Sea water [21] } \\
\cline { 1 - 4 } & 6.6 & $6.5-8.5$ & $6.5-8.5$ & $7-8$ \\
\hline TDH & 242500 & 1000 & 1000 & 35000 \\
\hline Sulphate $(\mathrm{mg} / \mathrm{L})$ & 2100 & 250 & 250 & 2710 \\
\hline Electrical Conductivity $(\mu \mathrm{S} / \mathrm{cm})$ & 19300 & 2500 & 2000 & - \\
\hline
\end{tabular}

\subsection{Electrocoagulation Process}

The electrocoagulation cell is an electrochemical separation procedure that uses the application of electrical current among sets of metal sheets called anodes. The metal anodes were flooded into a solution, as the coagulation factors destabilize the contamination. The electrocoagulation cell is made of glass material with a capacity of $3 \mathrm{~L}$ and a stirrer of $50 \mathrm{rpm}$, with which the terminals are connected to the power supply. The electrodes were connected at $0.1 \mathrm{mV}$. Electrodes of aluminum (99\% purity) and iron $(99.4 \%$ purity) were utilized in the electrocoagulation cell. The first electrocoagulation was performed using electrodes (anode and cathode) of iron (1.25 $\mathrm{mm}$ thickness and $120 \mathrm{~mm}$ diameter) as shown in Figure 1a. The second electrocoagulation was achieved using electrodes (anode and cathode) of aluminum as a rectangular plate $(140 \times 100 \times 1.5 \mathrm{~mm})$ as shown in Figure $1 \mathrm{~b}$. The distance between electrodes was set at $1.5 \mathrm{~cm}$. Since these two materials are widely used to treat contaminated water, the 
electrodes were placed after each experiment in hydrochloric acid (5\% volt/volt), washed with water, and then dried until they were used again.

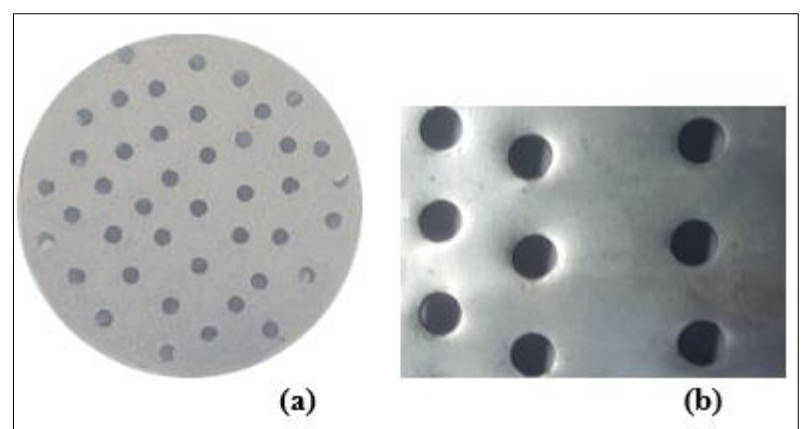

Figure 1. Electrodes used in electrocoagulation cell a. Iron electrode b. Aluminum electrode

\subsection{Adsorbent Material Preparation and Adsorption Process}

The modified silica was prepared by mixing the silica with $6 \mathrm{M}$ of $\mathrm{HCl}$ for $4 \mathrm{~h}$ and then treated with distilled water to get rid of the acid residue. The mixture was mixed with $2.5 \mathrm{M}$ of sodium hydroxide using magnetic stirrer for $6 \mathrm{~h}$. Drops of concentrated sulfuric acid solution were added to the mixture until it reached 8. The sediment was treated with Aqua Dest until the free base was obtained and transferred to the oven for drying. The modified silica surface area of $9 \mathrm{~m}^{2} / \mathrm{g}$ was determined using a surface area analyzer type (HORIBA SA - 9600 Series/USA). X-ray diffraction (XRD) type (Shimadzu Model AA-6800/ Japan) was used to distinguish the modified silica phases that had evolved. Scanning electron microscopy (SEM) Type (Thermo Fisher /USA) was used to clarify the surface morphology of modified silica. Atomic Force Microscope (AFM) type (220V, AA3000, Angstrom advanced Inc. America) includes a cantilever with a probe at its end that was used to scan the sample surface to determine the adsorbent surface roughness.

The adsorption process was achieved by adding modified silica to a one liter of produced water. Different modified silica doses $(0.2$ and $0.4 \mathrm{mg})$ and contact times $(30,60,90,120,150$, and $180 \mathrm{~min})$ during the adsorption process were used. During the adsorption process, the samples were shaken using a magnetic stirrer at $50 \mathrm{rpm}$ under the conditions of $25^{\circ} \mathrm{C}$ and $p \mathrm{H} 7$. The $p \mathrm{H}$ of the samples was controlled by the addition of $0.1 \mathrm{M} \mathrm{NaOH}$ to reach the required value. To accurately determine the $\mathrm{E}_{\mathrm{C}}$, the conductivity cell was rinsed with de-ionized water and loaded with the sample at $25^{\circ} \mathrm{C}$.

\section{Results and discussions}

\subsection{Electrocoagulation of Produced Water}

Electrocoagulation is an electrochemical technique that has many applications. It is evident from the literatures that electrocoagulation can be used to remove metal ions from wastewater [25-27]. The experimental results of this work show that the iron electrode corroded inside the electrolyte solution after 3 min due to the local dissolution of the iron and the spreading of pits within the electrode surface resulting in the deterioration of the iron electrode (Figure 2). According to (Tsuyuk et al., 2018) [28], the dissolution of iron during pitting corrosion is localized to the surface of the electrode where the passive protective film is destroyed. Also, according to (Wellner et al., 2018) [29] the $p \mathrm{H}$ solution inside the pit decreases due to generation of $\mathrm{H}^{+}$ion in the pit. On the other hand, $\mathrm{Cl}^{-}$moves from the electrolyte to the pit to maintain the lack of charge bias, thus increasing the affinity of the $\mathrm{Cl}^{-}$in the pit as the pit multiplies. Moreover, formation and hydrolysis of iron chloride $\left(\mathrm{FeCl}_{2}\right)$ occurs in the pit, and this leads to the evolution of the $\mathrm{H}^{+}$and the decrease in the $p \mathrm{H}$ of the pit. The decrease in the $p \mathrm{H}$ of the pit results in continued development of the pit. In addition, it can be shown that the failure of the electrocoagulation method is due to the high percentage of TDS in the produced water. Also, according to (Yavuz et al., 2010) [30], electrocoagulation has been found to be ineffective in treating Petroleum Refinery 
wastewater (PRW) due to the high amount of soluble organic pollutants and the low amount of suspended solids present in PRW.

Figure 3 shows that the aluminum electrodes failed upon initiation of the electrocoagulation to remove heavy metals in the first $5 \mathrm{~min}$ of $0.1 \mathrm{mV}$ due to the high concentration of sulfate ions in the produced water causing corrosion of these electrodes, these results agree with (Lee and Pyun, 2000) [31]. Therefore, electrocoagulation according to this study is not an effective method for treating produced water.

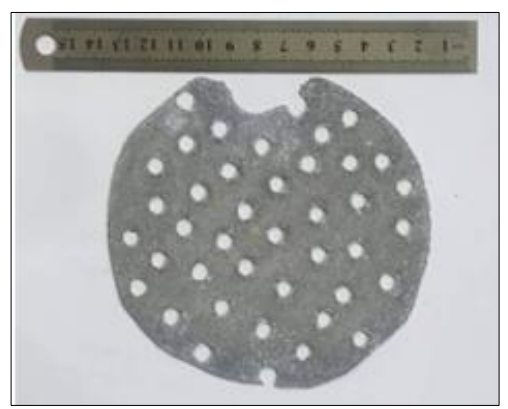

Figure 2. Iron electrode after electrocoagulation

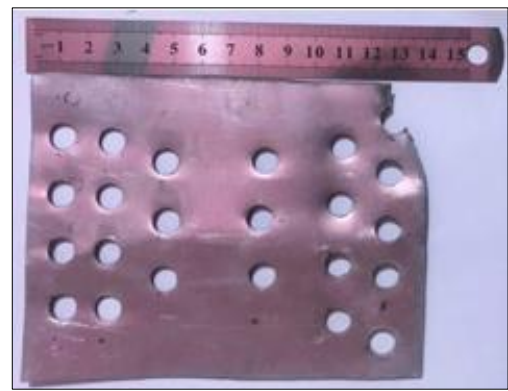

Figure 3. Aluminum electrode after electrocoagulation

\subsection{Characterization of Modified Silica}

Figure 4 shows the XRD pattern of modified silica. It is clear that the crystallographic reflection planes of modified silica correspond to peaks of the $\mathrm{SiO}_{2}$ phase. Intensity of the main peak of $26.6369^{\circ}$ is stronger than the two others of $20.8^{\circ}$ and $26.3^{\circ}$. It can be assigned that the modified silica categorized by $2 \theta$ at $26.6369^{\circ}, 20.8^{\circ}$ and $26.3^{\circ}$, which indicate the diffraction planes of (420), (220) and (420), respectively. SEM image of modified silica is shown in Figure 5. Obviously, modified silica has irregular particles shape. Analysis of particle size distribution of modified silica using laser granularity instrument indicates that the average diameter is $1.5968 \mu \mathrm{m}$.

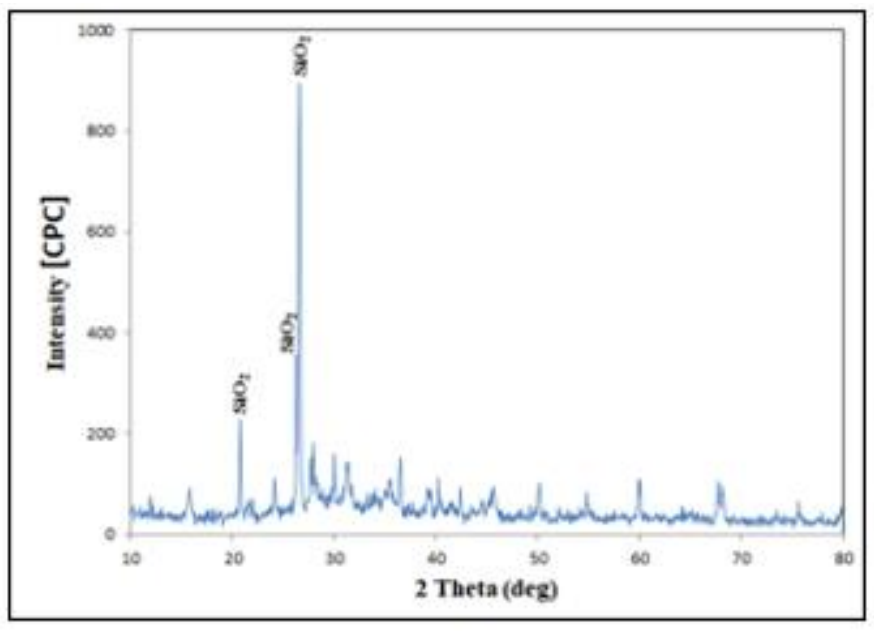

Figure 4. XRD pattern of modified silica

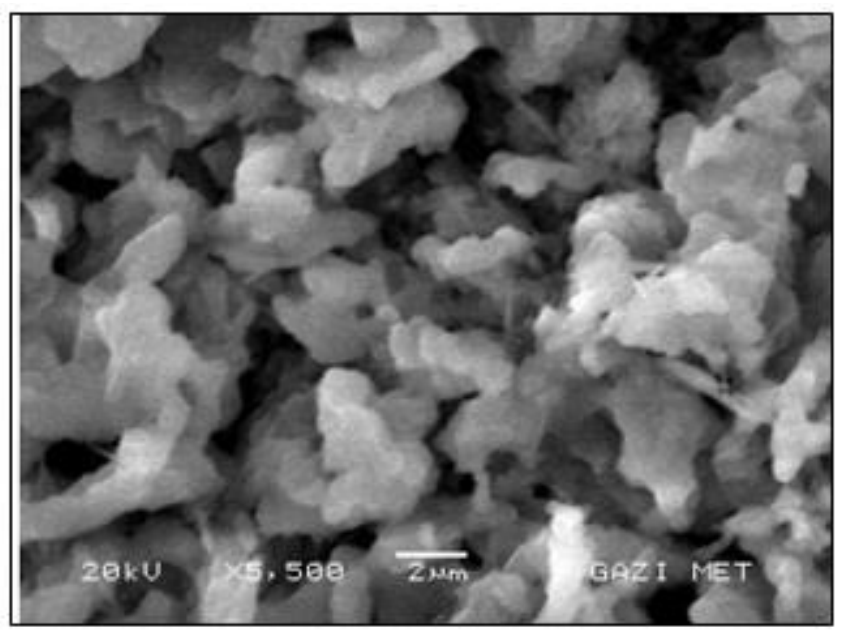

Figure 5. SEM image of modified silica

To recognize the adsorbent surface roughness of silica and modified silica, the surface roughness was measured by AFM. Figure 6 and Figure 7 show the two-dimensional (2D) and the three-dimensional (3D) images of the silica and modified silica, respectively, for $3 \mu \mathrm{m}$ x $3 \mu \mathrm{m}$ scan area and $600 \mathrm{~nm} \mathrm{z}$ scale. Bright areas represent the adsorbent particles peaks, while dark areas represent valleys corresponding to the pores between the adsorbent particles. The average surface roughness was 43.85 $\mathrm{nm}$ and 35.07 for silica and modified silica, respectively. Surface roughness plays an important role in adsorption. Although studies on the effect of surface roughness on the adsorb-ability are limited, the amount of adsorbate is inversely proportional to the surface roughness. Surface of adsorbent with less 
roughness have less free energy and less stress [32], thus the amount of adsorption is higher.

$\mathrm{Wu}$ et al., 2011 [33] explained that roughness has an inverse relationship with a hydrophobic adsorbent property and thus reduces adsorption. This emphasizes the importance of using modified silica instead of silica in treating the produced water. Improving the surfaces of the adsorbent material leads to a greater removal amount of the contaminants, whether they have either hydrophilic or hydrophobic properties [34].

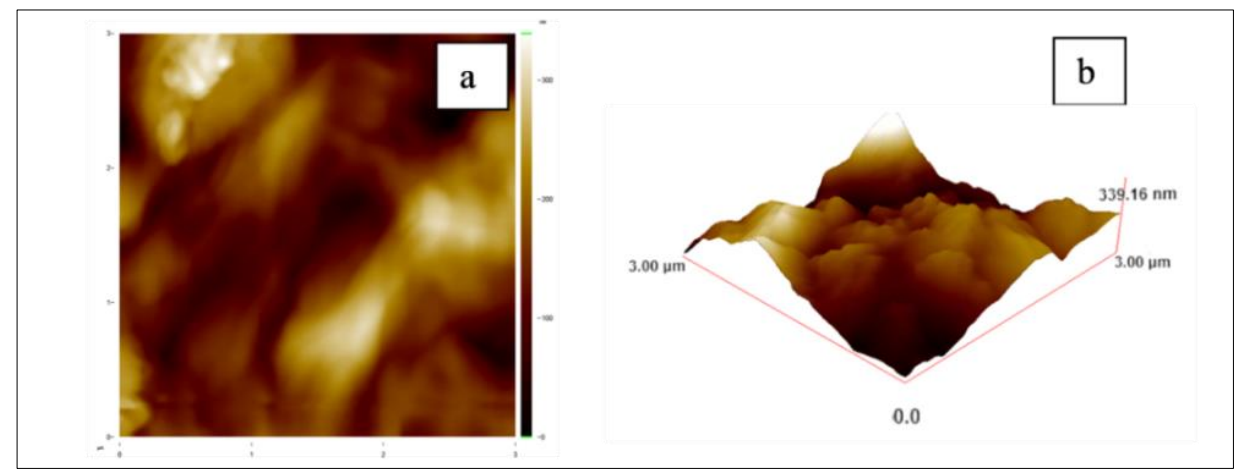

Figure 6. AFM image of silica (a) two-dimensional image, (b) three-dimensional image

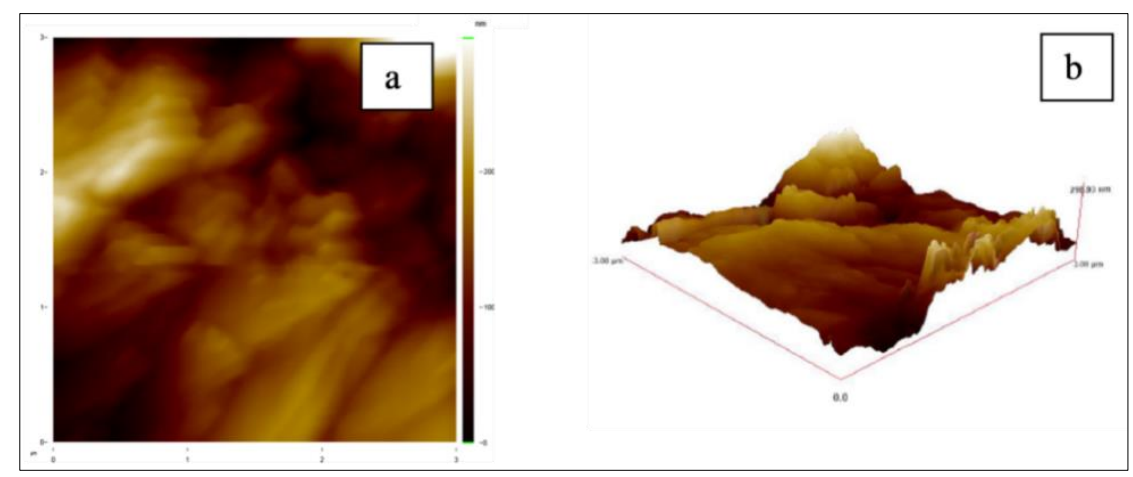

Figure 7. AFM image of modified silica (a) two-dimensional image, (b) three-dimensional image

\subsection{TDS and Ec of Adsorption Treated Produced Water}

Most of the produced water treatment technologies focus on reducing the values of TDS. Figure 8 shows the effect of different contact times on TDS of produced water using 0.2 and $0.4 \mathrm{mg}$ of modified silica. It is clear that TDS was decreased with increasing contact time from 30 to 180 min for 0.2 and $0.4 \mathrm{mg}$ of modified silica. Moreover, TDS was decreased with increasing modified silica dose from 0.2 to $0.4 \mathrm{mg}$ due to increased surface area of adsorbent. Different TDS values were obtained using adsorption method at different parameters. These values can be classified according to (Rusydi, 2018) [35] into two categories. The first category referred to fresh water with TDS content lower than 1000 $\mathrm{mg} / \mathrm{L}$. This category can be obtained using modified silica dose of $0.2 \mathrm{mg}$ at contact time of 150 and 180 $\mathrm{min}$. The fresh water can also be obtained using modified silica dose of $0.4 \mathrm{mg}$ at contact time in the range of 60-180 min. The second category referred to salty water with TDS content in the range of 1000$10000 \mathrm{mg} / \mathrm{L}$. This category can be obtained using $0.2 \mathrm{mg}$ of modified silica at contact times of 30-120 min while for $0.4 \mathrm{mg}$ of modified silica a contact time of $30 \mathrm{~min}$ is required. Therefore, treatment of produced water using modified silica with suitable dose and contact time to determine TDS value according to the World Health Organization making it appropriate for re-injection into oil wells. 


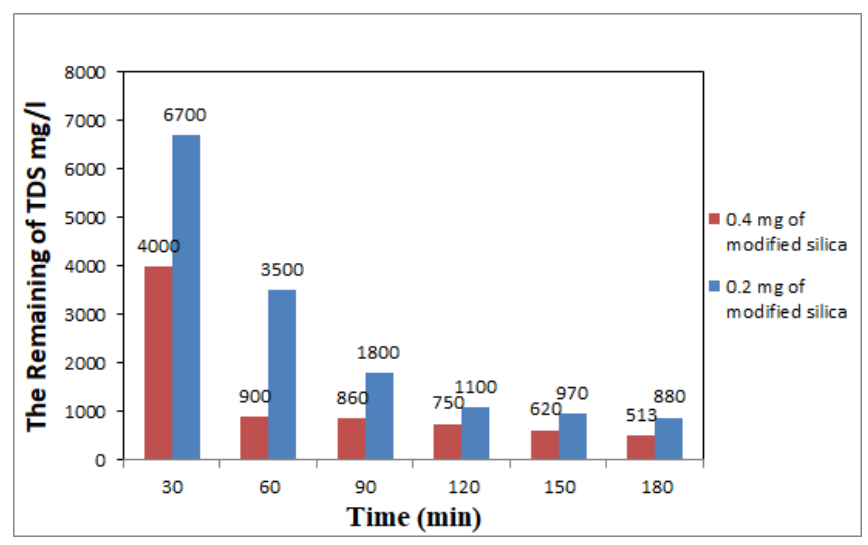

Figure 8. Effect of contact time on the TDS of produced water

Figure 9 shows the effect of different contact times on the $E_{C}$ of produced water treated using 0.2 and $0.4 \mathrm{mg}$ of modified silica. The $\mathrm{E}_{\mathrm{C}}$ of produced water can be characterized according to (Rusydi., 2018) [35], such as in kind $I$, when the salt content is low $\left(E_{C}<1500 \mu \mathrm{S} / \mathrm{cm}\right)$; kind II, when the salts content is medium $\left(\mathrm{E}_{\mathrm{C}}: 1500\right.$ to $\left.3000 \mu \mathrm{S} / \mathrm{cm}\right)$; and kind III, when the salts content is high $\left(\mathrm{E}_{\mathrm{C}}>3000\right.$ $\mu \mathrm{S} / \mathrm{cm}$ ). Therefore, adsorption treated produced water can be addressed under the type I (low enrichment of salts) at contact time of $180 \mathrm{~min}$ using $0.2 \mathrm{mg}$ of modified silica and at contact time of $60-180 \mathrm{~min}$ using $0.4 \mathrm{mg}$ of modified silica. Type II comprises of produced water that treated using $0.2 \mathrm{mg}$ of modified silica at contact time of 90-150 min, where these treated samples contained medium enrichment of salts. Type III contains high enrichment of salts and comprises of produced water that treated using $0.2 \mathrm{mg}$ of modified silica at contact times of 30 and $60 \mathrm{~min}$ and using $0.4 \mathrm{mg}$ of modified silica at contact time of $30 \mathrm{~min}$. It is clear from experimental results of $E_{C}$ that the increase in adsorbent dose and contact time contributed to a decrease in the $\mathrm{E}_{\mathrm{C}}$ value of produced water.

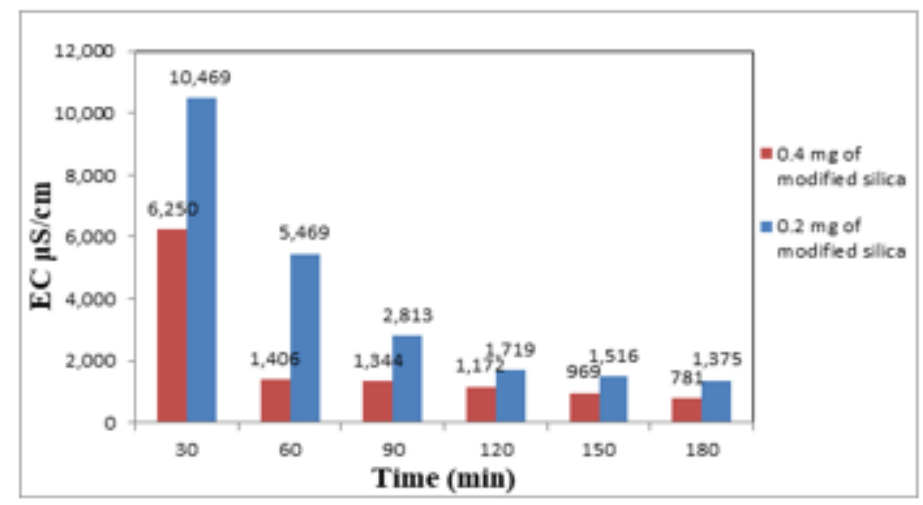

Figure 9. Effect of contact time on the $\mathrm{E}_{\mathrm{c}}$ of produced water

\section{Conclusions}

From the results of the current study, several conclusions can be addressed, which are represented by the following points:

1- Electrocoagulation failed to treat the produced water using iron-iron and aluminum-aluminum electrodes due to high amount of soluble pollutants.

2- Modified silica succeeded in removing the TDS and reducing the EC of the produced water.

3 - Increased contact time resulted in an increase in the removal of TDS and a decrease in EC value.

4- The use of $0.4 \mathrm{mg}$ of modified silica for removal TDS and reduce EC was significantly higher than that of $0.2 \mathrm{mg}$ of modified silica due to the increased surface area of the adsorbent. 
5- The adsorption treated produced water was suitable according to the WHO to be re-injected into the oil wells according to the TDS content and EC value using $0.2 \mathrm{mg}$ of modified silica at contact time of not less than $60 \mathrm{~min}$ while for $0.4 \mathrm{mg}$ of modified silica required at least $150 \mathrm{~min}$ of contact time.

\section{References}

1.Al-ZUHAIRI, F., AZEEZ, R., MAHDI, S., KADHIM, W., Al-NAAMEE, M., Removal oil from produced water by using adsorption method with adsorbent a papyrus reeds, Engineering and Technology Journal, 37, 2019, 157-165.

2.ANDRADE, V., T., ANDRADE, B., J., COSTA, B., R., PEREIRA, O., A., DEZOTTI, M., Toxicity assessment of oil field produced water treated by evaporative processes to produce water to irrigation, Water Sci Technol. 62, 2010, 693-700.

3.IGUNNU, E., T., CHEN, G., Z., Produced water treatment technologies, International Journal of LowCarbon Technologies, 9, 2014, 157-177.

4.LI, Y., Pretreatment of Oilfield Produced Water Using Ionic Liquids for Dissolved Air Floatation. MSc thesis, Petroleum systems engineering, University of Regina, 2017,1-138.

5.GAZALI, A., K., ALKALI, A., N., MOHAMMED, Y., DJAURO, Y., MUHAMMED, D, D., KODOMI, M, G., Environmental impact of produced water and drilling waste discharges from the niger delta petroleum industry, IOSR Journal of Engineering (IOSRJEN), 7, 2017,22-29.

6.Al-GHOUTI, M., A., Al-KAABI, M., A., ASHFAQ, M., Y., DANA, D., Produced water characteristics, treatment and reuse: a review, Journal of Water Process Engineering, 28, 2019, 222-239.

7.MANDA, U., K., BHARDWAJ, A., K., WARRINGTON, D., N., GOLDSTEIN, D., TAL, A., B., LEVY, G., J., Changes in soil hydraulic conductivity, runoff, and soil loss due to irrigation with different types of saline--sodic water, Geoderma, 144, 2008, 509-516.

8.***WORLD HEALTH ORGANIZATION, Guidelines for drinking-water quality, Geneva, 2008.

9.AL-SAAD, H., T., JAZZA, S., H., Quality assessment of drinking water in missan province, Iraq, International Journal of Marine, 6, 2016, 509-516.

10.NONATO, T., C., ALVES, A., SENS, M, L., DALSASSO, R., L., Produced water from oil - a review of the main treatment technologies, J environ. Chem. Toxico, 2, 2018, 23-27.

11.YAMAUCHI, S., INOUE, D., SUGANO, K., Permeation characteristics of tetracyclines in parallel artificial membrane permeation assay II: Effect of divalent metal ions and mucin, ADMET \& DMPK, 8, $2020,129-138$.

12.JING, G., REN, S., GAO, Y., SUN, W., GAO, Z., Electrocoagulation: a promising method to treat and reuse mineral processing wastewater with high COD, Water, 595, 2020,1-11.

13.AFANGA, H., ZAZOU, H., TITCHOU, F., RAKHILA, Y., AKBOUR, R., ELMCHAOURI, A., GHANBAJA, J., HAMDAN, M., Integrated electrochemical processes for textile industry wastewater treatment: system performances and sludge settling characteristics, Sustainable Environment Research, 30, 2020, 1-12.

14.CZIKKELY, M., NEUBAUER, E., FEKETE, I., YMERI, P., FOGARASSY, C., Review of heavy metal adsorption processes by several organic matters from wastewaters, Water Sci Technol, 10, 2018, $1-15$.

15.KARM, Z., SUBHI, A., D., HAMIED, R., S., Synthesis, characterization and application of gammaalumina as adsorbent material to enhance iron removal from produced water, U.P.B. Sci. Bull., Series B, 7, 2020, 237-246.

16.THAVAMANIL, S., RAJKUMAR, R., Removal of $\mathrm{Cr}$ (VI), Cu (II), Pb (II) and Ni (II) from aqueous solutions by adsorption on alumina, Research Journal of Chemical Sciences, 3, 2012, 1-9.

17.LI, Q., ZHANG, J., LU, Q., LU, J., LI, J., DONG, C., ZHU, Q., Hydrothermal synthesis and characterization of ordered mesoporous magnesium silicate-silica for dyes adsorption, Mater Let, 170, 2016, 167-170.

18.KARM, Z., SUBHI, A., D., HAMIED, R., S., Removal of iron from produced water using silica adsorbent material, Engineering and Technology Journal, 38, 2020, 1154-1159. 
19.SHENG, L., ZHANG, Y., TANG, F., LIU, S., Mesoporous/microporous silica materials: preparation from natural sands and highly efficient fixed-bed adsorption of methylene blue in wastewater, Microporous Mesoporous Mater, 257, 2018, 9-18.

20.IBTISSEM, S., FATIMA, Z., E., JOËLLE, D., NOR, E., F., ABDELKRIM, G., OUKACHA, G., BRAHIM, G., FERYAL, A., ILHEM, R., Mesoporous silica synthesized from natural local kaolin as an effective adsorbent for removing of acid red 337 and its application in the treatment of real industrial textile effluent, Processes, 8, 2020, 1-24.

21.***FilmTec ${ }^{\mathrm{TM}}$ Reverse Osmosis Membranes Technical Manual, Chapter 2, Water Chemistry and Pretreatment, 2020.

22.***ASTM Standard D5907-96A, Test method for filterable and nonfilterable matter in water, ASTM International, PA.

23.***ASTM Standard D 516 -02, Standard test method for sulfate ion in water, ASTM International, PA.

24.***ASTM Standard D 1125-95, Test method for electrical conductivity and resistivity of water" ASTM International, PA.

25.ABUZAID, N., S., BUKHARI, A., A., AL-HAMOUZ, Z., M., Ground water coagulation using soluble stainless steel electrodes, Advances in Environmental Research, 6, 2002, 325-333.

26.ZHOU, C., XUE, Y., LIU, X., CHEN, J., PENG, Y., TAN. W., Speciation Change of Flocs During Electrocoagulation for Wet Flue Gas Desulfurization Wastewater, Rev. Chim.,71(6), 2020, 321-326.

27.MIRON, A., CHIVU, A., RIKABI, A., ALBU, P., Pharmaceutical industry wastewater treatment through electrocoagulation, Rev. Chim., 65(12), 2014, 1399- 1406.

28.TSUYUK, C., YAMANAKA, A., OGIMOT, Y., Phase-field modeling for $\mathrm{pH}$ dependent general and pitting corrosion of iron, Sci EnTific Reports, 8, 2018, 1-14.

29.WELLNER, D., COUPERTHWAITE, S., MILLAR, G., Influence of operating parameters during electrocoagulation of sodium chloride and sodium bicarbonate solutions using aluminum electrodes, Journal of Water Process Engineering, 22, 2018, 13-26.

30.YAVUZ, Y., KOPARA, S., ÜLKER, Ö., Treatment of petroleum refinery wastewater by electrochemical methods, Desalination, 258, 2010, 201-205.

31.LEE, W., PYUN, S., Effects of sulphate ion additives on the pitting corrosion of pure aluminium in $0.01 \mathrm{~m} \mathrm{NaCl}$ solution, Electrochimica Acta, 45, 2000, 1901-1910.

32.RIAZIAN, M., Nanostructural characterization and lattice strain of $\mathrm{TiO}_{2}-\mathrm{Al}_{2} \mathrm{O}_{3} \mathrm{SiO}_{2}$ coating on glass and Si (100) substrates, Chilean Chemical Society., 61, 2016, 2870-2877.

33.WU, S., SHI, L., GARFIELD, L., B., TABOR, R., F., STRIOLO, A., GRADY, B., P., Influence of surface roughness on cetyltrimethylammonium bromide adsorption from aqueous solution, Langmuir. 27, 2011, 6091-6098.

34.WANG, L., SHI, C., WANG. L., PAN, L., ZHANG, X., ZOU, J., Rational design, synthesis, adsorption principles and applications of metal oxide adsorbents: a review, Nanoscale, 12, 2020, 47904815.

35.RUSYDI, A., IOP Conf. Series. Earth and Environmental Science, Bandung, Indonesia, 17-18 October, 2018, 1-6.

$\overline{\text { Manuscript received: } 6.09 .2020}$ 